\title{
Sistem Informasi Bimbingan Konseling menggunakan Metode Extreme Programming (Studi Kasus : SMK PGRI Tanjung Raja)
}

\author{
Muhammad Khatam ${ }^{1}$, Fenando ${ }^{2}$, Muhamad Kadafi ${ }^{3}$ \\ ${ }^{1}$ Sains dan Teknologi, Universitas Islam Raden Fatah, Palembang, Indonesia \\ 2,3Sistem Informasi, Universitas Islam Negeri Raden Fatah, Palembang, Idnonesia \\ Email: 1muh.khatam@gmail.com, 2fenando_uin@radenfatah.ac.id ${ }^{3}$ \\ kadafi_uin@radenfatah.ac.id
}

\begin{abstract}
Abstrak
SMK PGRI Tanjung Raja merupakan salah satu sekolah swasta yang berada di kecamatan Tanjung Raja kabupaten Ogan Ilir. saat ini permasalahan yang dihadapi oleh sekolah tersebut pada bagian bimbingan konseling masih secara manual menggunakan kertas sehingga menjadi kendala dalam perekapan, pencarian dan pembaharuan data mengingat banyaknya jumlah siswa. tujuan dari penelitian ini adalah membangun sebuah sistem informasi bimbingan konseling yang akan digunakan untuk memproses data bimbingan konseling secara komputerisasi mulai dari data siswa, data konseling, serta data pelanggaran siswa. penelitian ini menggunakan metode Extreme Programming dimana dalam proses pengembangan nya siap dalam menerima perubahan secara cepat. Hasil penelitian ini dapat memberikan kemudahan bagi sekolah untuk pendataan bagian bimbingan konseling nya serta bagi orang tua dapat mengetahui tingkah laku anaknya selama berada disekolah.
\end{abstract}

Kata Kunci: Sistem Informasi bimbingan konseling, Extreme Programming, Codelgniter.

\section{PENDAHULUAN}

SMK PGRI Tanjung Raja merupakan sekolah menengah kejuruan swasta yang memiliki beberapa jurusan dibidang teknologi industri. SMK PGRI Tanjung Raja terletak di kabupaten Ogan Ilir, Salah satu tujuan yang hendak dicapai oleh pihak instansi sekolah adalah pembentukan pribadi siswa yang berakhlak mulia. Untuk dapat menciptakan tujuan tersebut, maka dibentuklah tata tertib peserta didik yang dimana setiap pelanggaran tata tertib tersebut memiliki poin-poin tersendiri sesuai dengan jenis pelanggarannya, misalnya siswa terlambat masuk lebih dari 45 menit maka dikenakan 3 poin, membuang 
https://journal-computing.org/index.php/journal-sea/index

sampah sembarangan maka akan dikenakan 5 poin, atau bahkan melakukan tindak kriminal siswa akan dikenakan 50 poin pelanggaran. Setelah nilai poin pelanggaran diketahui, maka guru BK baru dapat memberikan tindakan kepada siswa yang melanggar dan memberikan sanksi sesuai dengan nilai poin pelanggarannya mulai dari diberikan peringatan oleh wali kelas dan guru BK (kurang dari 15 poin), membuat surat perjanjian yang dibubuhi tanda tangan diatas materai sampai pada tingkat yang paling tinggi dengan bobot atau nilai poin pelanggaran paling besar (100 poin) yaitu dikembalikan kepada orang tua atau wali.

Selain tata tertib, layanan bimbingan konseling juga ikut andil dalam menyelenggarakan dan menegakkan tujuan tersebut. Hasil wawancara saya dengan guru bimbingan konseling pada SMK PGRI Tanjung Raja, masih terdapat beberapa masalah dalam pelayanan bimbingan konseling seperti banyak poin pelanggaran yang tidak terakumulasi karena pencatatan masih menggunakan buku sehingga hasil perhitungannya sering tidak valid, selain itu dengan masih menggunakan buku wali murid dari siswa akan sulit mendapatkan informasi aktivitas bimbingan konseling dan pelanggaran apa saja yang telah dilakukan anaknya selama berada disekolah.

Berdasarkan kendala di atas, maka SMK PGRI Tanjung Raja membutuhkan sistem informasi bimbingan konseling yang dapat membantu dan memudahkan guru bimbingan konseling dalam melakukan pendataan dan pengolahan data siswa. Selain itu sistem informasi bimbingan konseling juga diharapkan dapat membantu orang tua atau wali siswa untuk berkonsultasi dengen guru bimbingan konseling. Rumusan masalah dalam penelitian ini adalah bagaimana membangun sistem informasi bimbingan konseling pada SMK PGRI Tanjung Raja. Tujuan yang ingin dicapai dari penelitian yang dilakukan yaitu membangun sistem informasi bimbingan konseling pada SMK PGRI Tanjung Raja.

\section{METODE}

Metode yang digunakan pada penelitian ini menggunakan metode Extreme Programming, Ada lima tahap pengembangan sistem dalam metode Extreme Programming digambarkan pada Gambar 1 


\section{Journal of Software Engineering Ampera}

Vol. 2, No. 3, October 2021 e-ISSN: 2775-2488

https://journal-computing.org/index.php/journal-sea/index

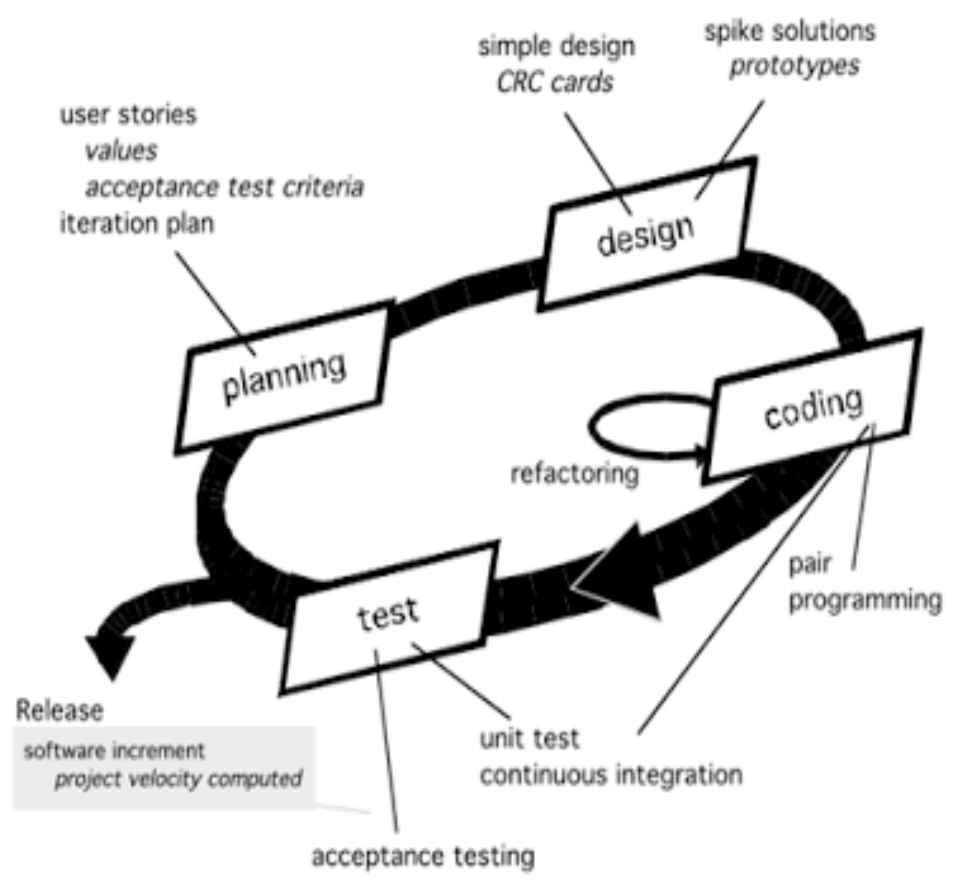

Gambar 1 Model Extreme Programming

Pada gambar diatas diperlihatkan tahapan yang dilalui sebagai berikut: 1). Pada tahap perencanaan ini dimulai dari pengumpulan kebutuhan untuk memahami konteks apa saja yang akan digunakan dalam sebuah sistem. Selain itu tahap ini juga mendefinisikan output yang akan dihasilkan. Disini penulis melakukan wawancara kepada guru bimbingan konseling di SMK PGRI Tanjung Raja. 2). Pada tahap ini dilakukan setelah perencanaan sistem (planning ). Tahap ini meliputi perancangan alur kerja sistem dan sistem database yang akan digunakan dalam sistem informasi bimbingan konseling. 3). Pada tahap ini merupakan proses pengkodean program berdasarkan hasil analisis dan rancangan sistem sebelumnya. Dalam tahap coding untuk membangun sistem informasi bimbingan konseling pada SMK PGRI Tanjung Raja ini penulis menggunakan Framework Codelgniter dan MySQL sebagai databasenya. 4). Tahap ini merupakan tahap terakhir pada penelitian ini. Pengujian dilakukan untuk memastikan fitur-fitur sistem berfungsi sesuai yang diharapkan dan apakah sistem yang dibangun berjalan tanpa ada permasalahan ataupun eror program. 


\section{Journal of Software Engineering Ampera}

Vol. 2, No. 3, October 2021 e-ISSN: 2775-2488

https://journal-computing.org/index.php/journal-sea/index

\section{HASIL DAN PEMBAHASAN}

\subsection{Planning (Perencanaan)}

Pada tahap ini dilakukan analisis secara langsung yaitu penulis melakukan observasi melalui wawancara dengan ibu Okta Meltri selaku guru bimbingan konseling untuk mendapatkan kebutuhan apa saja yang diperlukan dalam pembuatan sistem Bimbingan Konseling pada SMK PGRI Tanjung Raja.

\subsection{Design (Perancangan)}

Pada tahap ini penulis melakukan perancangan yang meliputi perancangan proses atau pola logika, perancangan database atau basis data, dan kemudian perancangan user interface.

Berikut merupakan UseCase Diagram yang digunakan dalam penelitian ini pada gambar 2.

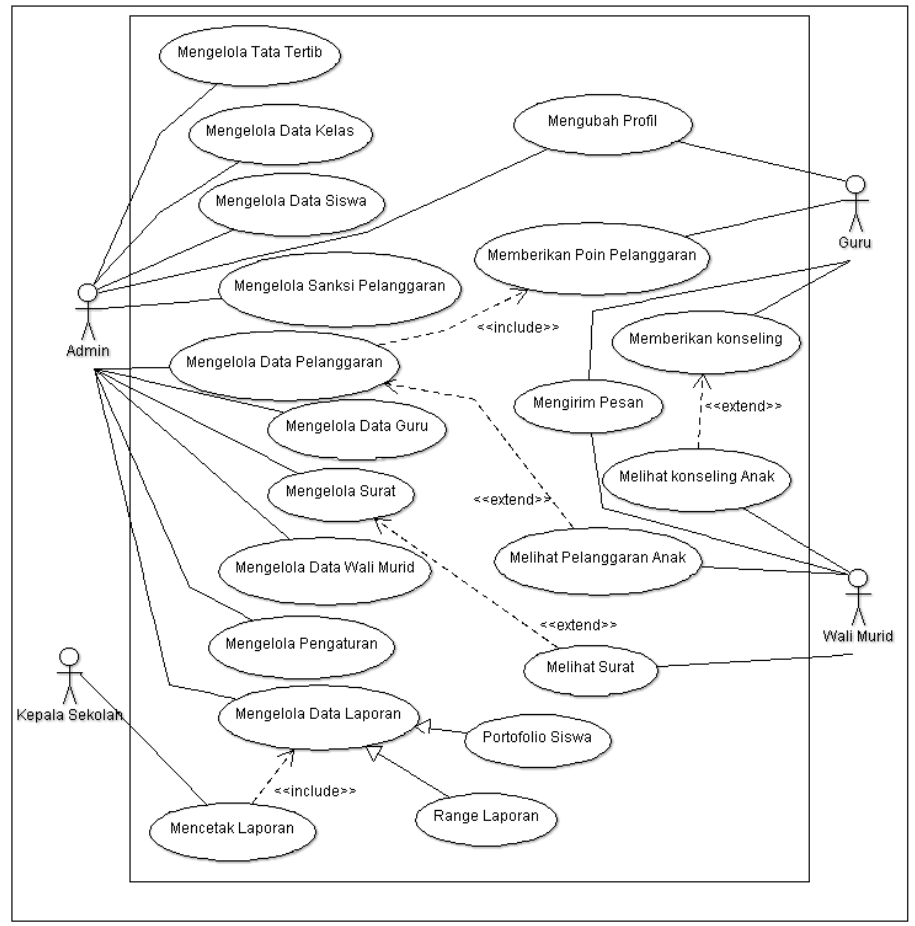

Gambar 2 Usecase Diagram 


\section{Journal of Software Engineering Ampera}

Vol. 2, No. 3, October 2021 e-ISSN: 2775-2488

https://journal-computing.org/index.php/journal-sea/index

Berikut merupakan ERD yang dibangun dalam penelitian ini pada gambar 3

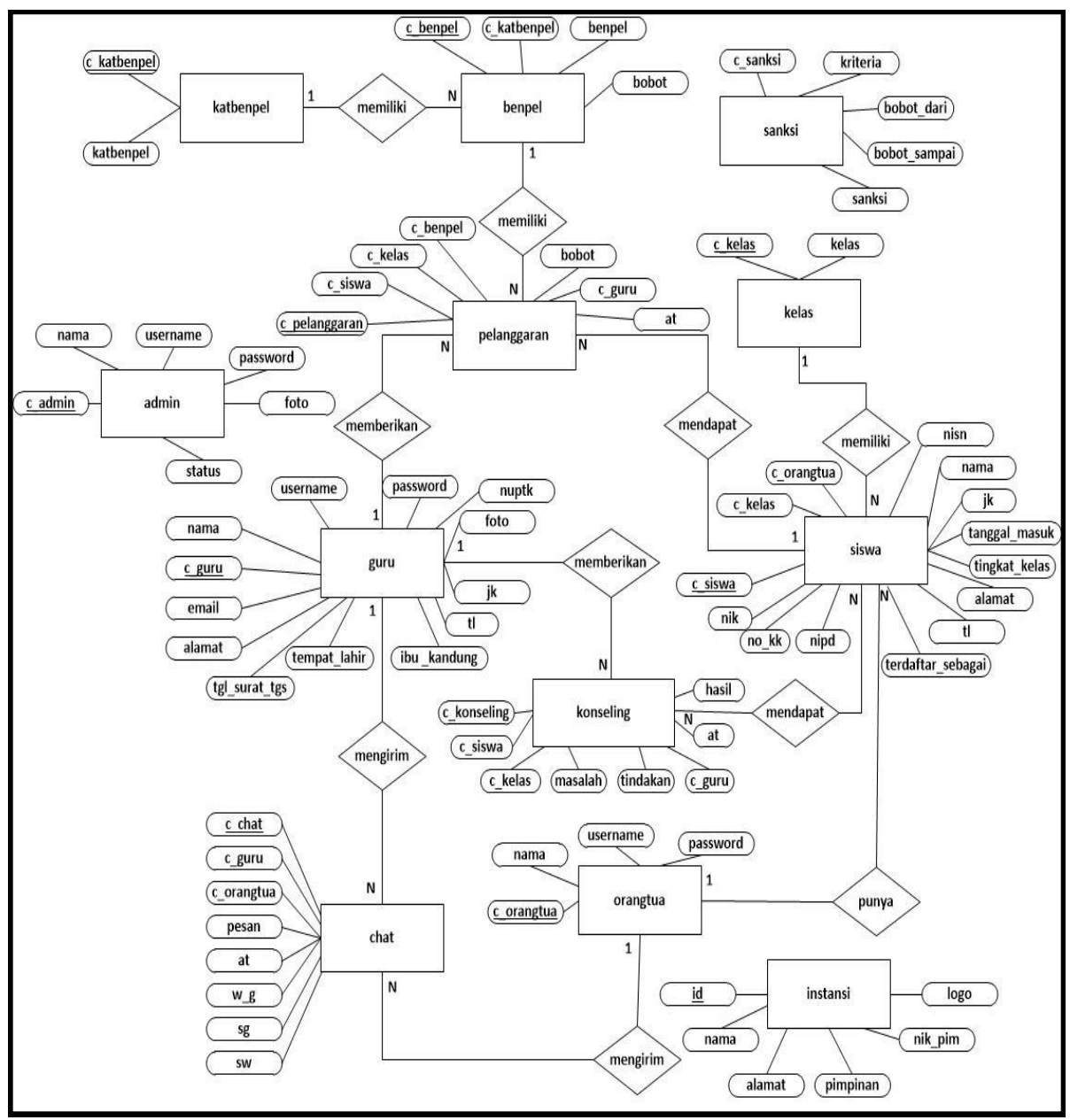

Gambar 3 Entity Relationship Diagram

\subsection{Coding (Implementasi Sistem)}

Berdasarkan pada hasil analisis dan perancangan yang telah dilakukan sebelumnya, maka pada tahap ini penulis akan melakukan tahapan implementasi. 
Journal of Software Engineering Ampera

Vol. 2, No. 3, October 2021 e-ISSN: 2775-2488

https://journal-computing.org/index.php/journal-sea/index

a. Tampilan Halaman Login

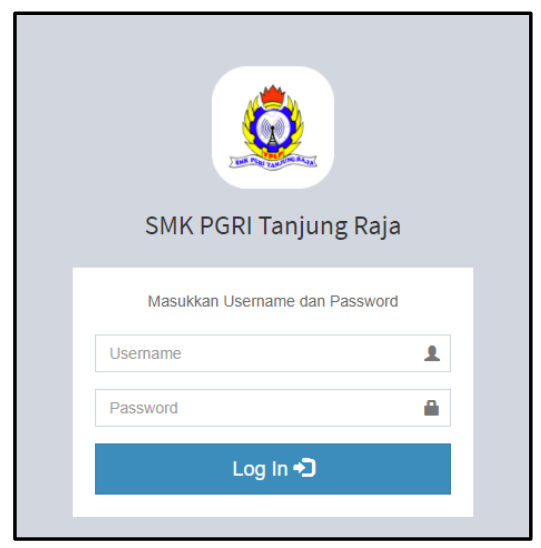

Gambar 4 Halam Login

b. Halaman Dashboard Admin

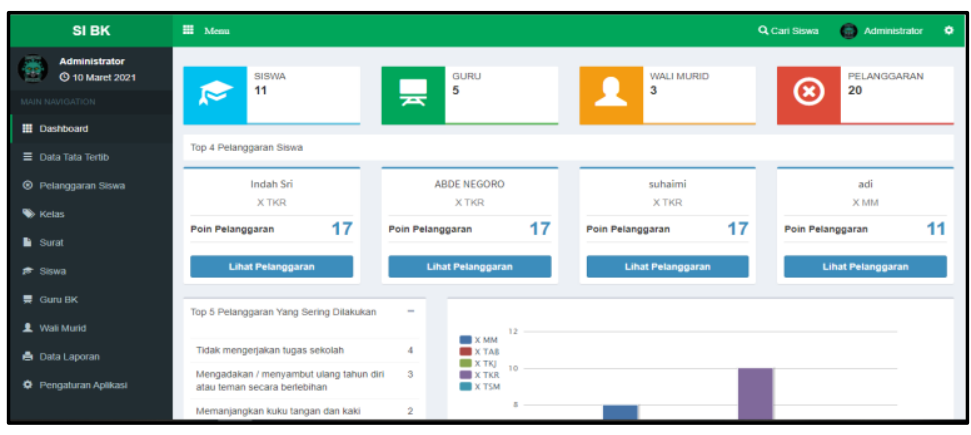

Gambar 5 Halaman Dashboard Admin

c. Halaman Dashboard Guru

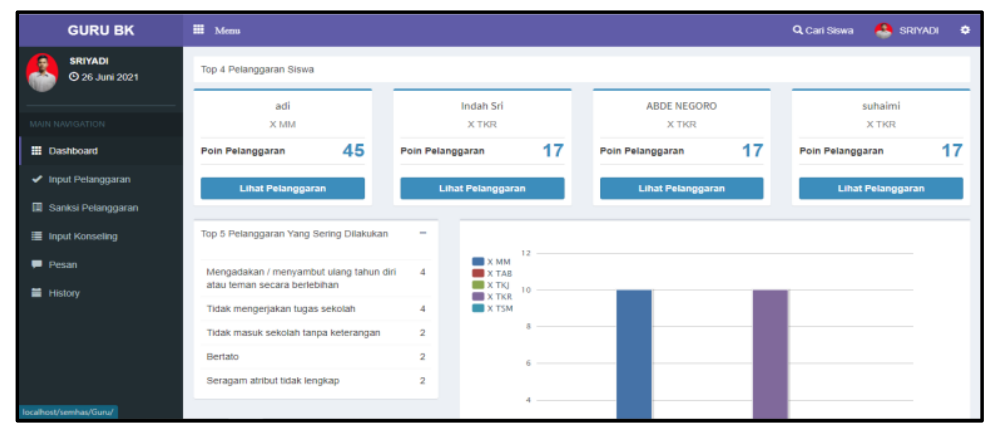

Gambar 6 Halaman Dashboard Guru

186 | Sistem Informasi Bimbingan Konseling menggunakan Metode.... 
Journal of Software Engineering Ampera

Vol. 2, No. 3, October 2021 e-ISSN: 2775-2488

https://journal-computing.org/index.php/journal-sea/index

d. Halaman Dashboard Wali Murid

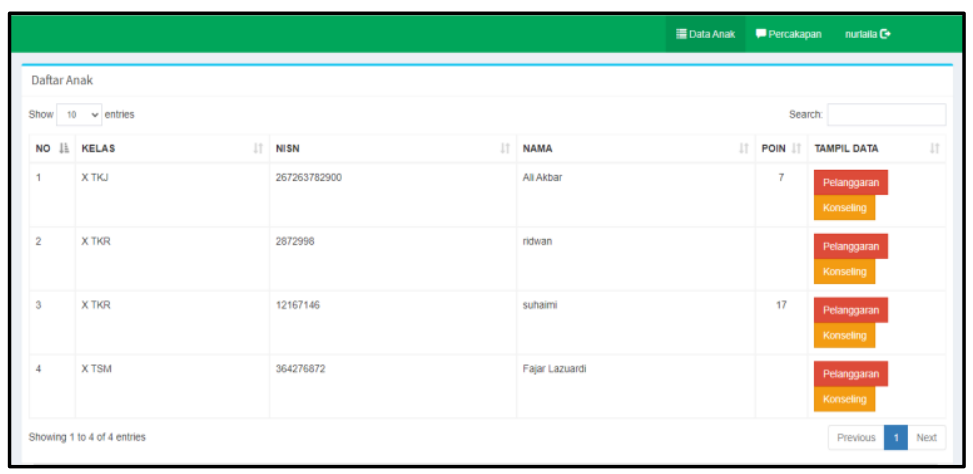

Gambar 7 Halaman Dashboard Wali Murid

e. Halaman Dashboard Kepala Sekolah

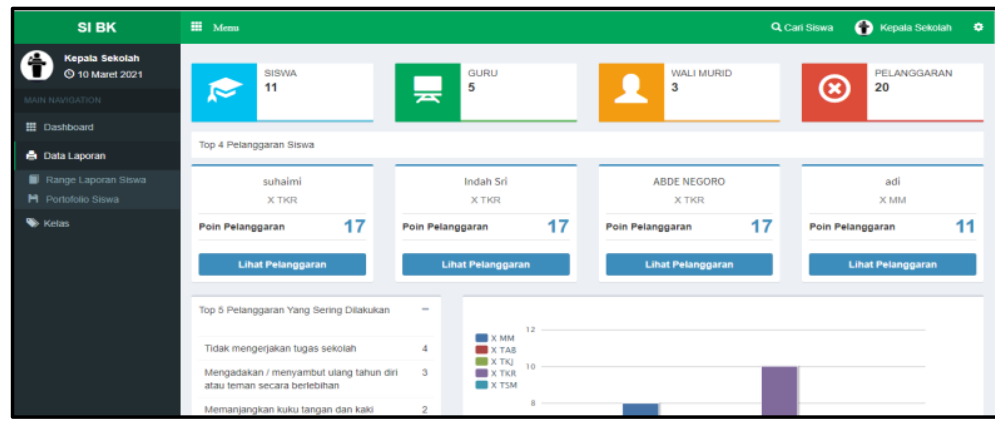

Gambar 8 Halaman Dashboard Kepala Sekolah

f. Halaman Data Anak

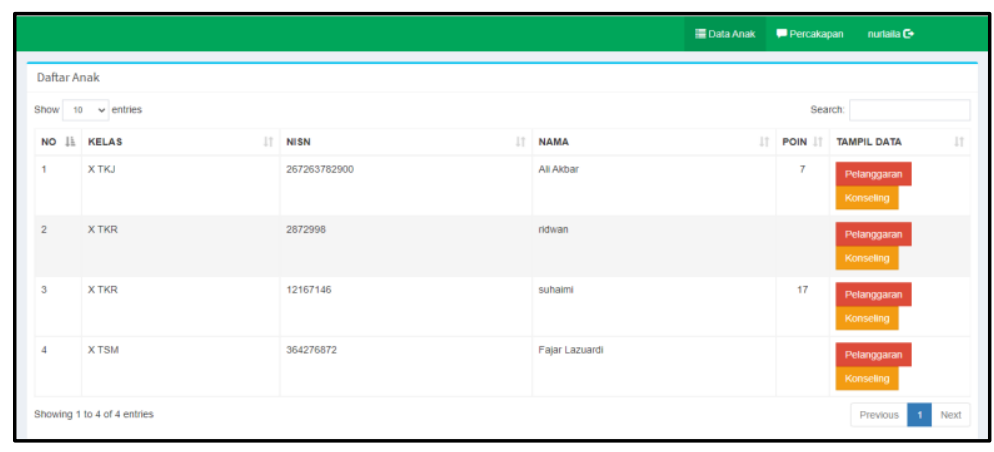

Gambar 9 Halaman Data Anak 
Journal of Software Engineering Ampera

Vol. 2, No. 3, October 2021 e-ISSN: 2775-2488

https://journal-computing.org/index.php/journal-sea/index

g. Halaman Pelanggaran Anak

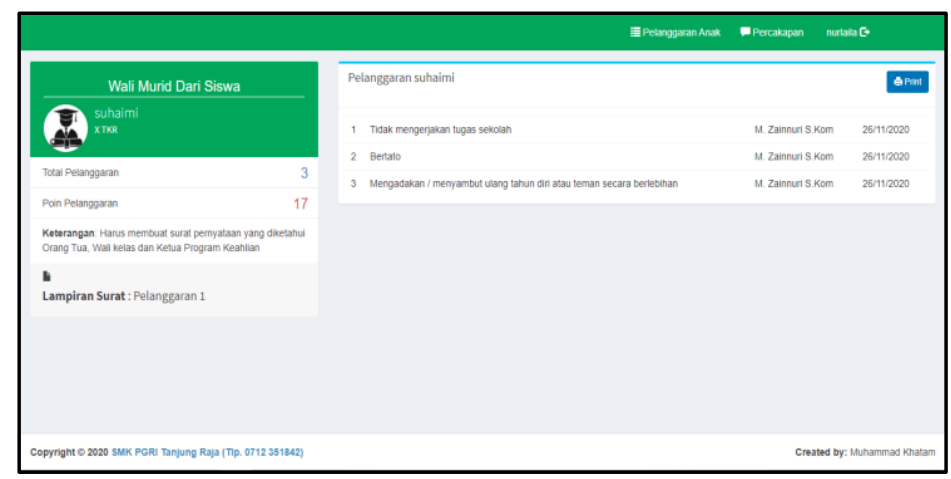

Gambar 10 Halaman Pelanggaran Anak

h. Halaman Konseling Anak

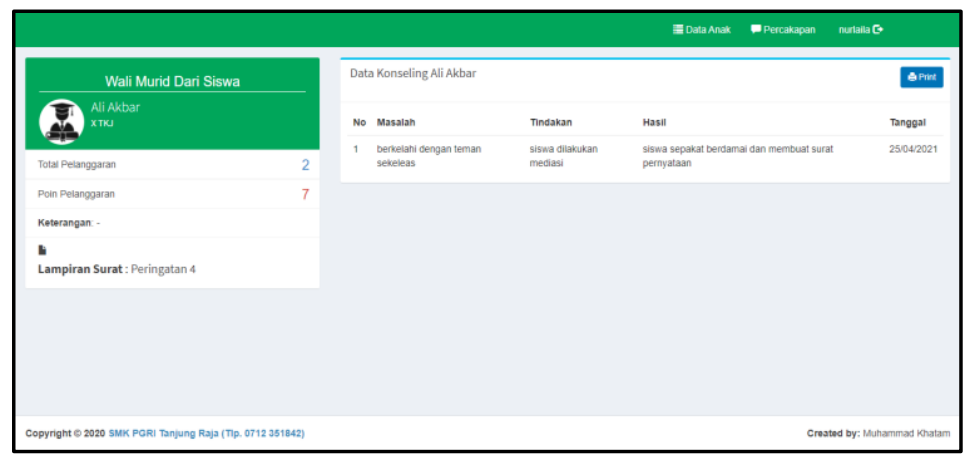

Gambar 11 Halaman Konseling Anak

i. Halaman Range Laporan

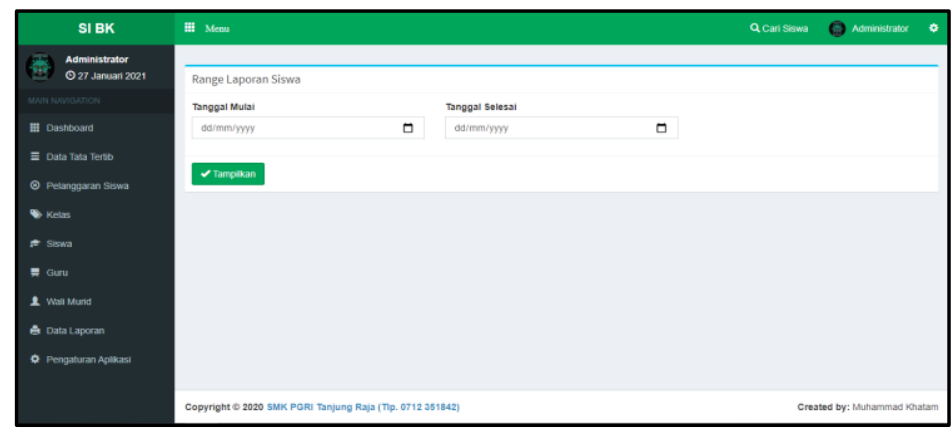

Gambar 12 Range Laporan

188 | Sistem Informasi Bimbingan Konseling menggunakan Metode.... 


\section{Journal of Software Engineering Ampera}

Vol. 2, No. 3, October 2021 e-ISSN: 2775-2488

https://journal-computing.org/index.php/journal-sea/index

\subsection{Testing (Pengujian)}

Pada tahap ini pengujian yang akan dilakukan dengan menggunakan metode pengujian blackbox. Penulis membuat scenario pengujian yang dilakukan oleh pengguna sistem yaitu : admin, guru, wali murid, dan kepala sekolah. Pengujian blackbox berupaya untuk menemukan kesalahan dalam kategori seperti: fungsi yang salah atau hilang, kesalahan antar muka, kesalahan perilaku atau kinerja, kesalahan dalam struktur data, dan kesalahan inisialisasi dan penghentian.

\section{a. Pengujian dilakukan oleh Admin}

Pengujian halaman Admin dilakukan bersama pengguna sistem yaitu Admin.

Tabel 1 Pengujian dilakukan oleh Admin

\begin{tabular}{|l|l|l|l|l|}
\hline No & $\begin{array}{l}\text { Fungsi yang } \\
\text { diuji }\end{array}$ & \multicolumn{1}{|c|}{ Cara Pengujian } & Hasil yang diharapkan & $\begin{array}{c}\text { Hasil } \\
\text { Pengujian }\end{array}$ \\
\hline 1 & Login & $\begin{array}{l}\text { Admin memasukan } \\
\text { username dan } \\
\text { password }\end{array}$ & $\begin{array}{l}\text { admin masuk kedalam } \\
\text { sistem } \begin{array}{l}\text { dan } \\
\text { menampilkan halaman } \\
\text { admin }\end{array}\end{array}$ & Berhasil \\
\hline 2 & $\begin{array}{l}\text { Kategori } \\
\text { Pelanggaran }\end{array}$ & $\begin{array}{l}\text { Klik menu kategori } \\
\text { pelanggaran }\end{array}$ & $\begin{array}{l}\text { Admin dapat melihat } \\
\text { kategori pelanggaran }\end{array}$ & Berhasil \\
\hline 3 & $\begin{array}{l}\text { Tambah } \\
\text { kategori } \\
\text { pelanggaran }\end{array}$ & $\begin{array}{l}\text { Menginput } \\
\text { kategori } \\
\text { pelanggaran }\end{array}$ & $\begin{array}{l}\text { Admin dapat } \\
\text { menambahkan kategori } \\
\text { pelanggaran }\end{array}$ & Berhasil \\
\hline 4 & $\begin{array}{l}\text { Edit kategori } \\
\text { pelanggaran }\end{array}$ & $\begin{array}{l}\text { Klik tombol edit } \\
\text { kategori } \\
\text { pelanggaran }\end{array}$ & $\begin{array}{l}\text { Admin dapat mengedit } \\
\text { kategori pelanggaran }\end{array}$ & Berhasil \\
\hline 5 & $\begin{array}{l}\text { Hapus } \\
\text { kategori } \\
\text { pelanggaran }\end{array}$ & $\begin{array}{l}\text { kategori } \\
\text { pelanggaran }\end{array}$ & $\begin{array}{l}\text { Admin } \\
\text { menghapus kategori } \\
\text { pelanggaran }\end{array}$ & Berhasil \\
\hline 6 & $\begin{array}{l}\text { Bentuk } \\
\text { pelanggaran }\end{array}$ & $\begin{array}{l}\text { Klik menu Bentuk } \\
\text { pelanggaran }\end{array}$ & $\begin{array}{l}\text { Admin dapat melihat } \\
\text { Bentuk pelanggaran }\end{array}$ & Berhasil \\
\hline 7 & $\begin{array}{l}\text { Tambah } \\
\text { Bentuk } \\
\text { pelanggaran }\end{array}$ & $\begin{array}{l}\text { Menginput Bentuk } \\
\text { pelanggaran }\end{array}$ & $\begin{array}{l}\text { Admin } \\
\text { menambahkan Bentuk } \\
\text { pelanggaran }\end{array}$ & Berhasil \\
\hline 8 & $\begin{array}{l}\text { Edit Bentuk } \\
\text { pelanggaran }\end{array}$ & $\begin{array}{l}\text { Klik tombol edit } \\
\text { Bentuk } \\
\text { pelanggaran }\end{array}$ & $\begin{array}{l}\text { Admin dapat mengedit } \\
\text { Bentuk pelanggaran }\end{array}$ & Berhasil \\
\hline
\end{tabular}




\section{Journal of Software Engineering Ampera}

Vol. 2, No. 3, October 2021 e-ISSN: 2775-2488

https://journal-computing.org/index.php/journal-sea/index

\begin{tabular}{|c|c|c|c|c|}
\hline 9 & $\begin{array}{l}\text { Hapus Bentuk } \\
\text { pelanggaran }\end{array}$ & $\begin{array}{l}\text { Klik tombol hapus } \\
\text { Bentuk } \\
\text { pelanggaran }\end{array}$ & $\begin{array}{lr}\text { Admin } & \text { dapat } \\
\text { menghapus } & \text { Bentuk } \\
\text { pelanggaran } & \\
\end{array}$ & Berhasil \\
\hline 10 & $\begin{array}{l}\text { Sanksi } \\
\text { pelanggaran }\end{array}$ & $\begin{array}{l}\text { Klik menu Sanksi } \\
\text { pelanggaran }\end{array}$ & $\begin{array}{l}\text { Admin dapat melihat } \\
\text { Sanksi pelanggaran }\end{array}$ & Berhasil \\
\hline 11 & $\begin{array}{l}\text { Tambah } \\
\text { Sanksi } \\
\text { pelanggaran }\end{array}$ & $\begin{array}{l}\text { Menginput Sanksi } \\
\text { pelanggaran }\end{array}$ & $\begin{array}{lr}\text { Admin } & \text { dapat } \\
\text { menambahkan } & \text { Sanksi } \\
\text { pelanggaran } & \\
\end{array}$ & Berhasil \\
\hline 12 & $\begin{array}{l}\text { Edit Sanksi } \\
\text { pelanggaran }\end{array}$ & $\begin{array}{l}\text { Klik tombol edit } \\
\text { Sanksi pelanggaran }\end{array}$ & $\begin{array}{l}\text { Admin dapat mengedit } \\
\text { Sanksi pelanggaran }\end{array}$ & Berhasil \\
\hline 13 & $\begin{array}{l}\text { Hapus Sanksi } \\
\text { pelanggaran }\end{array}$ & $\begin{array}{l}\text { Klik tombol hapus } \\
\text { Sanksi pelanggaran }\end{array}$ & $\begin{array}{lr}\text { Admin } & \text { dapat } \\
\text { menghapus } & \text { Sanksi } \\
\text { pelanggaran } & \\
\end{array}$ & Berhasil \\
\hline 14 & $\begin{array}{l}\text { Pelanggaran } \\
\text { siswa }\end{array}$ & $\begin{array}{l}\text { Klik menu } \\
\text { pelanggaran siswa }\end{array}$ & $\begin{array}{l}\text { Admin dapat melihat } \\
\text { pelanggaran siswa }\end{array}$ & Berhasil \\
\hline 15 & $\begin{array}{l}\text { Hapus } \\
\text { Pelanggaran } \\
\text { siswa } \\
\end{array}$ & $\begin{array}{l}\text { Klik tombol hapus } \\
\text { Pelanggaran siswa }\end{array}$ & $\begin{array}{l}\text { Admin dapat } \\
\text { menghapus } \\
\text { Pelanggaran siswa } \\
\end{array}$ & Berhasil \\
\hline 16 & $\begin{array}{l}\text { Laporan } \\
\text { pelanggaran } \\
\text { siswa }\end{array}$ & $\begin{array}{l}\text { Klik tombol print } \\
\text { Pelanggaran siswa }\end{array}$ & $\begin{array}{l}\text { Admin dapat mencetak } \\
\text { laporan Pelanggaran } \\
\text { siswa }\end{array}$ & Berhasil \\
\hline 17 & Data kelas & Klik menu kelas & $\begin{array}{l}\text { Admin dapat melihat } \\
\text { Data kelas }\end{array}$ & Berhasil \\
\hline 18 & $\begin{array}{l}\text { Tambah Data } \\
\text { kelas }\end{array}$ & $\begin{array}{l}\text { Menginput Data } \\
\text { kelas }\end{array}$ & $\begin{array}{lr}\text { Admin } & \text { dapat } \\
\text { menambahkan } & \text { Data } \\
\text { kelas } & \\
\end{array}$ & Berhasil \\
\hline 19 & $\begin{array}{l}\text { Edit Data } \\
\text { kelas }\end{array}$ & $\begin{array}{l}\text { Klik tombol edit } \\
\text { Data kelas }\end{array}$ & $\begin{array}{l}\text { Admin dapat mengedit } \\
\text { Data kelas }\end{array}$ & Berhasil \\
\hline 20 & $\begin{array}{l}\text { Hapus Data } \\
\text { kelas }\end{array}$ & $\begin{array}{l}\text { Klik tombol hapus } \\
\text { Data kelas }\end{array}$ & $\begin{array}{l}\text { Admin dapat } \\
\text { menghapus Data kelas }\end{array}$ & Berhasil \\
\hline 21 & Data Siswa & $\begin{array}{l}\text { Klik menu Data } \\
\text { Siswa }\end{array}$ & $\begin{array}{l}\text { Admin dapat melihat } \\
\text { Data Siswa }\end{array}$ & Berhasil \\
\hline 22 & $\begin{array}{l}\text { Tambah Data } \\
\text { Siswa }\end{array}$ & $\begin{array}{l}\text { Menginput Data } \\
\text { Siswa }\end{array}$ & $\begin{array}{lr}\text { Admin } & \text { dapat } \\
\text { menambahkan } & \text { Data } \\
\text { Siswa } & \\
\end{array}$ & Berhasil \\
\hline 23 & $\begin{array}{ll}\text { Edit } & \text { Data } \\
\text { Siswa } & \\
\end{array}$ & $\begin{array}{l}\text { Klik tombol edit } \\
\text { data Siswa }\end{array}$ & $\begin{array}{l}\text { Admin dapat mengedit } \\
\text { Data Siswa }\end{array}$ & Berhasil \\
\hline 24 & $\begin{array}{l}\text { Hapus Data } \\
\text { Siswa }\end{array}$ & $\begin{array}{l}\text { Klik tombol hapus } \\
\text { Data Siswa }\end{array}$ & $\begin{array}{l}\text { Admin dapat } \\
\text { menghapus Data Siswa }\end{array}$ & Berhasil \\
\hline 25 & Data Guru & $\begin{array}{l}\text { Klik menu Data } \\
\text { Guru }\end{array}$ & $\begin{array}{l}\text { Admin dapat melihat } \\
\text { Data Guru }\end{array}$ & Berhasil \\
\hline
\end{tabular}




\section{Journal of Software Engineering Ampera}

Vol. 2, No. 3, October 2021 e-ISSN: 2775-2488

https://journal-computing.org/index.php/journal-sea/index

\begin{tabular}{|c|c|c|c|c|}
\hline 26 & $\begin{array}{l}\text { Tambah Data } \\
\text { Guru }\end{array}$ & $\begin{array}{l}\text { Menginput Data } \\
\text { Guru }\end{array}$ & $\begin{array}{lr}\text { Admin } & \text { dapat } \\
\text { menambahkan } & \text { Data } \\
\text { Guru } & \\
\end{array}$ & Berhasil \\
\hline 27 & $\begin{array}{l}\text { Edit Data } \\
\text { Guru }\end{array}$ & $\begin{array}{l}\text { Klik tombol edit } \\
\text { Guru }\end{array}$ & $\begin{array}{l}\text { Admin dapat mengedit } \\
\text { Data Guru }\end{array}$ & Berhasil \\
\hline 28 & $\begin{array}{l}\text { Hapus Data } \\
\text { Guru }\end{array}$ & $\begin{array}{l}\text { Klik tombol hapus } \\
\text { Data Guru }\end{array}$ & $\begin{array}{l}\text { Admin dapat } \\
\text { menghapus Data Guru }\end{array}$ & Berhasil \\
\hline 29 & $\begin{array}{ll}\text { Data } & \text { Wali } \\
\text { murid } & \\
\end{array}$ & $\begin{array}{l}\text { Klik menu data wali } \\
\text { murid }\end{array}$ & $\begin{array}{l}\text { Admin dapat melihat } \\
\text { data wali murid }\end{array}$ & Berhasil \\
\hline 30 & $\begin{array}{l}\text { Tambah data } \\
\text { wali murid }\end{array}$ & $\begin{array}{l}\text { Menginput data } \\
\text { wali murid }\end{array}$ & $\begin{array}{lr}\text { Admin } & \text { dapat } \\
\text { menambahkan } & \text { data } \\
\text { wali murid } & \end{array}$ & Berhasil \\
\hline 31 & $\begin{array}{l}\text { Edit data wali } \\
\text { murid }\end{array}$ & $\begin{array}{l}\text { Klik tombol edit } \\
\text { data wali murid }\end{array}$ & $\begin{array}{l}\text { Admin dapat mengedit } \\
\text { data wali murid }\end{array}$ & Berhasil \\
\hline 32 & $\begin{array}{l}\text { Hapus data } \\
\text { wali murid }\end{array}$ & $\begin{array}{l}\text { Klik tombol hapus } \\
\text { data wali murid }\end{array}$ & $\begin{array}{l}\text { Admin dapat } \\
\text { menghapus data wali } \\
\text { murid }\end{array}$ & Berhasil \\
\hline 33 & Data Surat & Klik menu surat & $\begin{array}{l}\text { Admin dapat melihat } \\
\text { data Surat }\end{array}$ & Berhasil \\
\hline 34 & Tambah surat & Menginput surat & $\begin{array}{l}\text { Admin dapat } \\
\text { menambahkan surat }\end{array}$ & Berhasil \\
\hline 35 & Edit surat & $\begin{array}{l}\text { Klik tombol edit } \\
\text { surat }\end{array}$ & $\begin{array}{l}\text { Admin dapat mengedit } \\
\text { data surat }\end{array}$ & Berhasil \\
\hline 36 & $\begin{array}{l}\text { Hapus data } \\
\text { wali murid }\end{array}$ & $\begin{array}{l}\text { Klik tombol hapus } \\
\text { surat }\end{array}$ & $\begin{array}{l}\text { Admin dapat } \\
\text { menghapus data surat }\end{array}$ & Berhasil \\
\hline 37 & $\begin{array}{l}\text { Range } \\
\text { laporan }\end{array}$ & $\begin{array}{l}\text { Menginput tanggal } \\
\text { mulai dan tanggal } \\
\text { selesai }\end{array}$ & $\begin{array}{l}\text { Admin dapat melihat } \\
\text { dan mencetak statistik } \\
\text { laporan berdasarkan } \\
\text { rentang waktu }\end{array}$ & Berhasil \\
\hline 38 & $\begin{array}{l}\text { Portofolio } \\
\text { siswa }\end{array}$ & $\begin{array}{l}\text { Klik menu } \\
\text { portofolio siswa }\end{array}$ & $\begin{array}{l}\text { Admin dapat melihat } \\
\text { dan mencetak } \\
\text { portofolio siswa }\end{array}$ & Berhasil \\
\hline 39 & $\begin{array}{l}\text { Pengaturan } \\
\text { aplikasi }\end{array}$ & $\begin{array}{l}\text { Menginput } \\
\text { informasi } \\
\text { diperlukan } \\
\end{array}$ & $\begin{array}{l}\text { Informasi berubah } \\
\text { sesuai dengan yang } \\
\text { diinputkan admin }\end{array}$ & Berhasil \\
\hline 40 & Menu akun & $\begin{array}{l}\text { Menginput } \\
\text { akun admin }\end{array}$ & $\begin{array}{l}\text { Data berubah sesuai } \\
\text { dengan yang diinputkan } \\
\text { admin }\end{array}$ & Berhasil \\
\hline 41 & Logout & Klik menu logout & $\begin{array}{l}\text { Admin keluar dari } \\
\text { halaman admin }\end{array}$ & Berhasil \\
\hline
\end{tabular}




\section{Journal of Software Engineering Ampera}

Vol. 2, No. 3, October 2021 e-ISSN: 2775-2488

https://journal-computing.org/index.php/journal-sea/index

\section{b. Pengujian dilakukan oleh Guru}

Pengujian halaman guru dilakukan bersama pengguna sistem yaitu guru.

Tabel 2 Pengujian dilakukan oleh Guru

\begin{tabular}{|c|c|c|c|c|}
\hline No & $\begin{array}{c}\text { Fungsi yang } \\
\text { diuji }\end{array}$ & Cara Pengujian & $\begin{array}{l}\text { Hasil yang } \\
\text { diharapkan }\end{array}$ & $\begin{array}{c}\text { Hasil } \\
\text { Pengujian }\end{array}$ \\
\hline 1 & Login & $\begin{array}{l}\text { guru memasukan } \\
\text { username dan } \\
\text { password }\end{array}$ & $\begin{array}{l}\text { Guru masuk kedalam } \\
\text { sistem dan } \\
\text { menampilkan } \\
\text { halaman admin }\end{array}$ & Berhasil \\
\hline 2 & $\begin{array}{l}\text { Input } \\
\text { pelanggaran }\end{array}$ & $\begin{array}{l}\text { Guru memilih } \\
\text { siswa dan } \\
\text { menginputkan } \\
\text { pelanggaran yang } \\
\text { dilakukan }\end{array}$ & $\begin{array}{l}\text { Data serta poin } \\
\text { pelanggaran siswa } \\
\text { bertambah }\end{array}$ & Berhasil \\
\hline 3 & $\begin{array}{l}\text { Input } \\
\text { konseling }\end{array}$ & $\begin{array}{l}\text { Guru memilih } \\
\text { siswa dan } \\
\text { menginputkan } \\
\text { konseling yang } \\
\text { dilakukan }\end{array}$ & $\begin{array}{l}\text { Data konseling siswa } \\
\text { berhasil bertambah }\end{array}$ & Berhasil \\
\hline 4 & $\begin{array}{l}\text { Sanksi } \\
\text { pelanggaran }\end{array}$ & $\begin{array}{l}\text { Klik menu Sanksi } \\
\text { pelanggaran }\end{array}$ & $\begin{array}{l}\text { Guru dapat melihat } \\
\text { Sanksi pelanggaran }\end{array}$ & Berhasil \\
\hline 5 & Pesan & $\begin{array}{l}\text { Guru memilih wali } \\
\text { murid dan } \\
\text { mengirimkan } \\
\text { pesan }\end{array}$ & $\begin{array}{l}\text { Wali murid menerima } \\
\text { pesan yang dikirim } \\
\text { oleh guru }\end{array}$ & Berhasil \\
\hline 6 & History & Klik menu history & $\begin{array}{l}\text { Guru dapat melihat } \\
\text { history pelanggaran } \\
\text { yang } \\
\text { diberikannya }\end{array}$ & Berhasil \\
\hline 7 & Hapus history & $\begin{array}{l}\text { Klik tombol hapus } \\
\text { pada history }\end{array}$ & $\begin{array}{l}\text { Guru dapat } \\
\text { menghapus } \\
\text { pelanggaran siswa }\end{array}$ & Berhasil \\
\hline 8 & $\begin{array}{l}\text { Laporan } \\
\text { history }\end{array}$ & $\begin{array}{l}\text { Klik tombol print } \\
\text { pada history }\end{array}$ & $\begin{array}{l}\text { Guru dapat mencetak } \\
\text { pelanggaran siswa } \\
\text { yang telah diberikan }\end{array}$ & Berhasil \\
\hline 9 & Ganti foto & $\begin{array}{l}\text { Klik tombol ganti } \\
\text { foto }\end{array}$ & $\begin{array}{l}\text { Guru dapat } \\
\text { mengganti foto profil } \\
\text { nya }\end{array}$ & Berhasil \\
\hline
\end{tabular}


Journal of Software Engineering Ampera

Vol. 2, No. 3, October 2021 e-ISSN: 2775-2488

https://journal-computing.org/index.php/journal-sea/index

\begin{tabular}{|l|l|l|l|l|}
\hline 10 & Logout & Klik menu logout & $\begin{array}{l}\text { guru keluar dari } \\
\text { halaman guru }\end{array}$ & Berhasil \\
\hline
\end{tabular}

\section{c. Pengujian dilakukan oleh Wali Murid}

Pengujian halaman wali murid dilakukan bersama pengguna sistem yaitu wali murid.

Tabel 3 Pengujian dilakukan oleh Wali Murid

\begin{tabular}{|l|l|l|l|l|}
\hline No & $\begin{array}{c}\text { Fungsi yang } \\
\text { diuji }\end{array}$ & \multicolumn{1}{|c|}{ Cara Pengujian } & \multicolumn{1}{|c|}{$\begin{array}{c}\text { Hasil yang } \\
\text { diharapkan }\end{array}$} & \multicolumn{1}{c|}{$\begin{array}{c}\text { Hasil } \\
\text { Pengujian }\end{array}$} \\
\hline 1 & Login & $\begin{array}{l}\text { Wali murid } \\
\text { memasukan } \\
\text { username dan } \\
\text { password }\end{array}$ & $\begin{array}{l}\text { Wali murid masuk } \\
\text { kedalam sistem dan } \\
\text { menampilkan } \\
\text { halaman wali murid }\end{array}$ & Berhasil \\
\hline 2 & $\begin{array}{l}\text { Pelanggaran } \\
\text { anak }\end{array}$ & $\begin{array}{l}\text { Wali murid memilih } \\
\text { data anaknya }\end{array}$ & $\begin{array}{l}\text { Wali murid dapat } \\
\text { melihat poin } \\
\text { pelanggaran apa saja } \\
\text { yang dilakukan } \\
\text { anaknya }\end{array}$ & Berhasil \\
\hline 3 & $\begin{array}{l}\text { Konseling } \\
\text { anak }\end{array}$ & $\begin{array}{l}\text { Wali murid memilih } \\
\text { data anaknya }\end{array}$ & $\begin{array}{l}\text { Wali murid dapat } \\
\text { melihat konseling } \\
\text { apa saja yang } \\
\text { dilakukan anaknya }\end{array}$ & Berhasil \\
\hline 4 & Percakapan & $\begin{array}{l}\text { Wali murid memilih } \\
\text { guru dan } \\
\text { mengirimkan pesan }\end{array}$ & $\begin{array}{l}\text { Guru menerima } \\
\text { pesan yang dikirim } \\
\text { oleh wali murid }\end{array}$ & Berhasil \\
\hline 5 & Logout & Klik menu logout & $\begin{array}{l}\text { Wali murid keluar } \\
\text { dari halaman wali } \\
\text { murid Berhasil }\end{array}$ & \\
\hline
\end{tabular}

d. Pengujian dilakukan oleh Kepala Sekolah

Pengujian halaman kepala sekolah dilakukan bersama pengguna sistem yaitu kepala sekolah. 
Journal of Software Engineering Ampera

Vol. 2, No. 3, October 2021 e-ISSN: 2775-2488

https://journal-computing.org/index.php/journal-sea/index

Tabel 4 Pengujian dilakukan oleh Kepala Sekolah

\begin{tabular}{|c|c|c|c|c|}
\hline No & $\begin{array}{c}\text { Fungsi yang } \\
\text { diuji }\end{array}$ & Cara Pengujian & $\begin{array}{l}\text { Hasil yang } \\
\text { diharapkan }\end{array}$ & $\begin{array}{c}\text { Hasil } \\
\text { Pengujian }\end{array}$ \\
\hline 1 & Login & $\begin{array}{l}\text { Kepala sekolah } \\
\text { memasukan } \\
\text { username dan } \\
\text { password }\end{array}$ & $\begin{array}{lr}\text { Kepala } & \text { sekolah } \\
\text { masuk } & \text { kedalam } \\
\text { sistem } & \text { dan } \\
\text { menampilkan } & \\
\text { halaman } & \text { kepala } \\
\text { sekolah } & \end{array}$ & Berhasil \\
\hline 2 & $\begin{array}{l}\text { Range } \\
\text { Laporan } \\
\text { Siswa }\end{array}$ & $\begin{array}{ll}\text { Kepala } & \text { sekolah } \\
\text { memilih } & \text { rentang } \\
\text { waktu } & \end{array}$ & $\begin{array}{l}\text { Kepala sekolah dapat } \\
\text { melihat statistik data } \\
\text { berdasarkan rentang } \\
\text { waktu yang dipilih }\end{array}$ & Berhasil \\
\hline 3 & $\begin{array}{l}\text { Portofolio } \\
\text { siswa }\end{array}$ & $\begin{array}{l}\text { Klik menu } \\
\text { portofolio siswa }\end{array}$ & $\begin{array}{l}\text { Kepala sekolah dapat } \\
\text { melihat dan } \\
\text { mencetak portofolio } \\
\text { siswa }\end{array}$ & Berhasil \\
\hline 4 & Kelas & Klik menu kelas & $\begin{array}{l}\text { Kepala sekolah dapat } \\
\text { melihat dan } \\
\text { mencetak } \\
\text { pelanggaran } \\
\text { berdasarkan kelas }\end{array}$ & Berhasil \\
\hline 4 & Logout & Klik menu logout & $\begin{array}{l}\text { Wali murid keluar } \\
\text { dari halaman wali } \\
\text { murid }\end{array}$ & Berhasil \\
\hline
\end{tabular}

\section{KESIMPULAN}

Berdasarkan penelitian dengan judul Sistem Informasi Bimbingan Konseling menggunakan Metode Extreme Programming (Studi Kasus : SMK PGRI Tanjung Raja) maka dapat diambil kesimpulan adalah sistem informasi bimbingan konseling ini dibangun dengan menggunakan bahsa pemrograman PHP yang menggunakan Framework Codelgniter dan MySQL sebagai database serta untuk metode pengembangan sistemnya menggunakan metode Extreme Programming. Sistem informasi bimbingan konseling ini dapat membantu serta mempermudah guru bimbingan konseling untuk melakukan pendataan serta pengolahan data konseling pada SMK PGRI Tanjung Raja. 
https://journal-computing.org/index.php/journal-sea/index

\section{Daftar Pustaka}

[1] A.S, Rosa, dan Shalahuddin, M. 2015. Rekayasa Perangkat Lunak Terstruktur Dan Berorientasi Objek, Bandung : Informatika.

[2] Ngurah Suryatara, I Gusti. 2017 : Merancang Applikasi dengan Metodologi Extreme Programming. Jakarta : Elex Media Komputindo.

[3] Prayitno, dan Amti Erman. 2014, Dasar-dasar Bimbingan dan Konseling, Jakarta : Rineka Cipta.

[4] Pressman Roger S. 2012. Rekayasa Perangkat Lunak Pendekatan Praktisi Edisi 7 Terjermahan : Adi Nugroho, George John Leopold Nikijuluw, Theresia Herlina Rochadiani, dan Ike Kurniawati Wijaya, Yogyakarta : Penerbit Andi.

[5] Subagia, A. (2018). Kolaborasi Codelgniter dan Ajax dalam Perancangan CMS. Jakarta: Elex Media Komputindo. 